\title{
(In)formal Migrant Settlements and Right to Respect for a Home
}

\author{
Lieneke Slingenberg \\ Vrije Universiteit, Amsterdam, The Netherlands \\ c.h.slingenberg@vu.nl \\ Louise Bonneau* \\ Vrije Universiteit, Amsterdam, The Netherlands \\ l.bonneau@hotmail.com
}

\begin{abstract}
Across European cities, migrants without access to state facilities, resort to living in 'makeshift camps' or squats. These settlements are usually evacuated and demolished by state authorities. Instead of discussing the state's positive obligation to provide decent housing, this article focusses solely on the state's negative obligations under the right to respect for a home as laid down in Article 8 of the European Convention of Human Rights (ECHR). Drawing upon the cases of Calais and Amsterdam, this article scrutinizes domestic case law about evictions from (in)formal migrant settlements and compares that to case law of the European Court of Human Rights (ECtHR). We argue that the ECtHR case law provides a relevant framework that should be used to evaluate the legitimacy of evictions and destructions of (in)formal migrants' settlements. Despite the fact that applying this framework would not entail a complete ban on evictions, it would provide some welcome (procedural and substantive) protection for migrants.
\end{abstract}

* Thanks to Jeroen Doomernik, Tamara Last, Bas Schotel, Thomas Spijkerboer and the anonymous referee for their useful comments on earlier drafts. Preliminary results and earlier versions of this article have been presented at the DAMR Fall meeting on 'Urban Refugees and Migrant Integration in the City' (18 November 2016, Tilburg University) and at a colloquium of the Paul Scholten Centre for Jurisprudence (21 March 2017, University of Amsterdam). We thank all participants for their suggestions and comments.

(C) LIENEKE SLINGENBERg AND LOUISE BONNEAU, 2017 | DOI 10.1163/15718166-12340013

This is an open access article distributed under the terms of the prevailing CC-BY-NC license at the time of publication. 


\section{Keywords}

irregular migrants - Calais camps - squats - Article 8 ECHR - Right to Respect for a Home - evictions

\section{Introduction}

The poorest man may in his cottage bid defiance to all the forces of the Crown. It may be frail; its roof may shake; the wind may blow through it; the storm may enter; the rain may enter; but the King of England cannot enter-all his force dares not cross the threshold of the ruined tenement! ${ }^{1}$

Over 60 percent of the world's 19.5 million refugees reside in urban areas. ${ }^{2}$ This trend is echoed in the European Union (EU) where migrants and refugees are overwhelmingly located in European cities. ${ }^{3}$ As a result, cities are increasingly recognized as the gateway to basic services (i.e. healthcare, housing and education).$^{4}$

1 Remarks attributed to William Pitt, Earl of Chatham, on the occasion of debate in Parliament on the searches incident to the enforcement of an excise on cider, cited in USC Miller $v$. United States (1958), with reference in footnote 7 to The Oxford Dictionary of Quotations (2d ed. 1953), 379. In Hansard, Parliamentary History of England (1813), vol. 15, column 1307, under the proceedings in the Commons on the cider tax in March, 1763, we find: 'Mr. Pitt spoke against this measure, particularly against the dangerous precedent of admitting the officers of excise into private houses. Every man's house was his castle, he said.'). Our thanks to Bas Schotel for referring us to this illustrative quote.

2 UNHCR, 'Urban Refugees', http://www.unhcr.org/urban-refugees.html, accessed 3 January 2017; OECD, 'The Economic Impact of Migration: Why the Local Level Matters', in: OECD, International Migration Outlook 2016 (Paris: OECD, 2017).

3 Eurostat, 'Urban Europe-statistics on cities, towns and suburbs-foreign-born persons living in cities', http:// ec.europa.eu/eurostat/statistics-explained/index.php/Urban _Europe_\%E2\%80\%94_statistics_on_cities,_towns_and_suburbs_\%E2\%80\%94_foreignborn_persons_living_in_cities, accessed 3 January 2017.

4 The Urban Agenda for Eu (established by the 'Pact of Amsterdam' Agreed at the Informal Meeting of EU Ministers Responsible for Urban Matters on 30 May 2016 in Amsterdam, The Netherlands http://ec.europa.eu/regional_policy/sources/policy/themes/urban -development/agenda/pact-of-amsterdam.pdf, accessed 3 January 2017) signals a political shift towards this recognition at the European Union Level. It must be noted however that a key obstacle for cities dealing with migrants and refugees is competency: whether a city would like to respond to, for instance, migrant homelessness by expelling (rejected) asylum seekers (thus effectively removing them from the city) or regularising their legal status (in 
At the same time, across European cities such as Paris, Berlin, Amsterdam, Calais and Patra, (rejected) asylum seekers and refugees without access to state facilities, have often resorted to living in 'makeshift camps' or squats. These settlements are subsequently 'often evacuated and demolished (...) sometimes only to be erected again in a different form or location'. ${ }^{5}$ A prominent example is Calais, where French policy and practice since the end of the 1990s, has resulted in a cyclical pattern of (in)formal settlement creation and destruction. In Amsterdam, the issue of informal migrant settlements has begun more recently. Since 2012, the 'We are here' protest group has been evicted from many empty buildings in which they had squatted or, by way of exception, been provided. The interventions in Calais and Amsterdam are the result of a complex set of intersecting, sometimes conflicting, local, regional and national legal regimes, policies and interests.

The issue of irregular migrants' poor living conditions has been analysed in terms of socio-economic rights and positive obligations on the part of the State. ${ }^{6}$ While the homelessness of (vulnerable) irregular migrants provides indeed strong incentives to explore states' obligations to provide some kind of shelter, the proliferation of migrants' makeshift camps and squats across the European Union has made it equally pressing to treat the question of eviction and demolition adequately. This latter issue touches upon the state's negative obligation; the obligation not to interfere with migrants' rights. We believe it is important to not only focus on what the state should provide to (irregular) migrants, but also on when the state should refrain from acting. In this way, state restraint has the capacity to take due consideration for the homes migrants made for themselves, irrespective of the housing options and conditions, and places important attention the modalities and timing of the evictions. The personal scope of this more classic function of human rights, connected to civil and political rights, is less controversial than the scope of positive obligations

order to enable their integration into the local community), actions of local authorities will be limited by their legal mandate. On the role of cities, also see: V. Mamadouh \& A. van Wageningen, Urban Europe: Fifty Tales of the City (Amsterdam: AUP, 2016).

5 I. Katz, 'A Network of Camps on the Way to Europe', $5_{1}$ Forced Migration Review (2016) 17.

6 See for example: C. Breen, 'The Policy of Direct Provision in Ireland: A violation of Asylum Seekers' Right to an Adequate Standard of Housing', 20 International Journal of Refugee Law (2008) 611; S. Da Lomba, 'The ECHR and the Protection of Irregular Migrants in the Social Sphere', 22 International Journal on Minority and Group Rights (2015) 39; P. Schoukens \& D. Pieters, Exploratory Report on the Access to Social Protection for Illegal Labour Migrants (Strasbourg: Council of Europe, 2004); G. Vonk, 'Access to Social Protection for Non-Citizen Migrants: The Position of Irregular Immigrants', in: R. Plender (ed.), Issues in International Migration Law (2015) 81-91, at 81. 
and socioeconomic rights, which is usually restricted to migrants with (some kind of) lawful residence. ${ }^{7}$ For irregular migrants, therefore, negative state obligations could provide important protection, which deserves more scholarly attention.

In this article, we will focus solely on the state's negative obligations under the right to respect for a home as laid down in Article 8 of the European Convention of Human Rights (ECHR). Drawing upon the cases of Calais and Amsterdam, this paper investigates the meaning and relevance of the European Court of Human Rights (ECtHR) case-law on the negative obligations under Article 8 for the practice of evicting migrants from (in)formal settlements. To this end, the paper will scrutinize domestic case law about evictions from (in)formal migrant settlements and compare it to relevant rules and factors used in the case law of the ECtHR on the negative obligations under the right to respect for a home. The term '(in)formal' is used to indicate that, even though the cases discussed in this article concern evictions from makeshift camps and squats, these dwellings have sometimes been established at the state's or local authorities' instigation or have been officially tolerated by these authorities.

It must be noted that the aim is not to romanticize and downplay the harsh living conditions, such as lack of access to water and sanitary infrastructure, faced by migrants in the camps and squats, and the real effects on mental and physical health. An emphasis on negative obligations could justify lack of action by states and cities, thereby adversely affecting the provision of basic services and fuel the marginalisation of migrants. Instead, this paper concentrates on negative obligations in order to explore whether focussing on the state's negative obligations with regard to the issue of housing has any added value for the discussion about irregular migrants' rights.

We argue that the framework of testing evictions and dismantlements in the light of Article $8 \mathrm{ECHR}$, as developed in the case law of the ECtHR, is a relevant and useful framework which should be used to evaluate the legitimacy of evictions and destructions of informal migrants' settlements. Yet we observe that in the domestic case law about evictions and dismantlements in Calais and Amsterdam, the application of this framework is extremely limited; it is either not at all invoked or applied, or, when applied, this is done only in a superficial way. Even though an increased use of the Article 8 ECH R framework in

7 See for an overview of lawful residence conditions connected to positive state obligations stemming from international refugee law, social security law and human rights law: L. Slingenberg, The Reception of Asylum Seekers under International Law. Between Sovereignty and Equality (Oxford: Hart Publishing, 2014). 
domestic case law will not prevent all future evictions, we contend that it could influence the mode in which they are carried out and the interests that should be taken into account in these cases.

It may be asked why Calais and Amsterdam were chosen for this research. Both having recently received strong media attention, they were selected first out of familiarity with their contexts. Moreover, although at first glance two very distinct cases, various discussions led us to observe strong similarities in the practice evictions and/or dismantlements and how domestic case-law appeared to address this practice. It is these similarities which sparked an interest for in-depth research.

Our approach was the same for both Calais ${ }^{8}$ and Amsterdam. First, we contextualised the evictions and/or dismantlements by examining existing literature, policy documents and news articles. We then identified all existing national case law by scrutinising national databases. ${ }^{9}$ From this exercise,

8 The situation for migrants in Calais is both fast-changing and closely intertwined with camps across the North of France. While the settlement in Calais is the most well-known, the north of France holds a number of other camps, such as Grande-Synthe, Norrent-Fontes and Steenvorde. For more information see Jean-Baptiste François, 'Coincés, face à l'Angleterre' (2 January 2016, Quotidien no. 40397, La Croix), http://services.la-croix.com/webdocs/pages/ longform_camps_calais/index.html). As a result, it must be highlighted that the primary focus of this research is Calais and does not take into account developments post November 2016.

9 The French case-law was identified using national database LegiFrance in both the administrative case-law and constitutional case-law databases (https://www.legifrance.gouv.fr/). The following general search terms were used: 'Calais', 'migrants', 'réfugié, 'éxilé, 'éviction'. Case-law was also identified using the jurisprudence available on the website of the nongovernmental organisation supporting immigrants Gisti (Groupe d'information et de soutien des immigre.e.s, http://www.gisti.org/spip.php?article17o) and the information available on the blog 'Passeurs d'hospitalite' (https://passeursdhospitalites.wordpress.com/). The Dutch case-law was identified using national database Rechtspraak. The following general search terms were used: 'we are here', 'wij zijn hier', 'vluchteling /vreemdeling / rechtmatig verblijf + ontruiming / ontruimen / ontruimd', 'vluchteling / vreemdeling / rechtmatig verblijf + kraakpand / kraken / gekraakt'. In addition, the names of all different locations of the We are here group, as mentioned on their website (http://wijzijnhier.org/tijdslijn/geschiedenis-van-wijzijn-hier/, last accessed 7 February 2017), have been entered in the case law database (eg. Notweg, Vluchtgarage, Vluchtkerk etc). 
we found a limited number of published judgments on the evictions and dismantlements of migrants' camps and squats in Amsterdam (as from 2012) and Calais (as from 2014). ${ }^{10}$ This case-law was then closely and systematically analysed.

For sketching the relevant Article 8 ECHR framework of analysis, we have used traditional legal doctrinal analysis. ${ }^{11}$ Relevant case law has been selected by using the HUDOC database ${ }^{12}$ and from these cases we have deduced general rules and relevant factors.

\section{3}

(In)formal Migrant Settlements in Calais and Amsterdam

\subsection{Calais}

Located in northern France, a mere thirty-three kilometres from the south-east English coast and the port of Dover, Calais has long been a place of transition to the United Kingdom (UK) for non-EU migrants. ${ }^{13}$ In an effort to reduce irregular migration, French and British policies and practices focus on controlling human mobility and securitising their common border. ${ }^{14}$ As a result, since the opening of the Channel tunnel in 1994, entry into the UK has become increasingly difficult, the period of time spent by migrants in Calais has increased, and diverse settlements punctuated the region. Many migrants in Calais intend to make an application for international protection. However they mostly wish to

10 Although the desk research on Calais leads us to identify (in)formal settlement creations and destructions from 1999 to 2016, the first published case-law found dates back to 2014 . Therefore the legal analysis is focused on the June 2014 to May 2017 period.

11 E.H. Tiller \& F.B. Cross, 'What is Legal Doctrine?', 100 Northwestern University Law Review (2006) 517-533; W.B. Wendel, 'Explanation in Legal Scholarship: The Inferential Structure of Doctrinal Analysis', 96 Cornell Law Review (2011) 1035-1074.

12 Only judgments have been examined, no decisions. The keyword 'Article 8-1 Respect for home' was used to identify relevant cases.

13 K. Akoka \& O. Clochard, 'Dans La Jungle des Villes', 48 Vacarme (2009) 86-91, http://www .vacarme.org/article179o.html, accessed 15 February 2016; S. Prestianni, 'Calais, Patras, Subotica: Les “Jungles de l'Europe"', in: M. Agier (ed.), Un monde de camps (Paris: La Découverte, 2014), pp. 369-386.

14 M. Bosworth, 'Juxtaposed Border Controls and Penal Power on the French North Coast', in: Border Criminologies Blog, 24 February 2016, www.law.ox.ac.uk/research-subject-groups/ centre-criminology/centreborder-criminologies/blog/2016/o2/juxtaposed-border, accessed 3 May 2016; G. Clayton, 'The U K and Extra-Territorial Immigration Control: Entry Clearance and Juxtaposed Controls', in: B. Ryan \& V. Mitsilegas (eds.), Extraterritorial Immigration Control: Legal Challenges (Leiden: Brill, 2010), pp. 391-423. 
do so in the United Kingdom rather than in France. Therefore, although most are potential asylum seekers, ${ }^{15}$ until Calais migrants file for asylum in France, they will be treated as irregular migrants by the authorities. ${ }^{16}$ This results in settlements with a very diverse population.

Around four distinct periods of (in)formal settlement creation and destruction can be identified since the end of the 1990s. 'The Sangatte Centre' (1999 to 2002) and the 'Pachtoune Jungle' (2002 to 2009) constitute the first two examples of the (in)formal settlement creation and destruction pattern. This was followed by a period of city camps and squats (2009-2014) which culminated with an authorised eviction in 2014. More recently, 'a (state) township' (20152016) emerged at the outskirts of the city. Though the size, location, nature and organisation of these settlements differed, ${ }^{17}$ French authorities have consistently deployed a 'policy of invisibilisation' to deter migrant transition in Calais, remove migrants from the public eye and pretend that the migrant 'problem' is solved. ${ }^{18}$ In practice, this policy has allowed the French government to systematically evict migrants and dismantle the settlements.

\subsubsection{French Legal Framework for Evictions}

In France, ${ }^{19}$ squatting is not a criminal offence. Individuals squatting however, may be pursued for other reasons such as damage to property. ${ }^{20}$ Except for special circumstances (detailed below), expulsions can only be enforced through a court decision. ${ }^{21}$ The status of the terrain, public or private, determines which competent authority can decide upon an eviction request: the 'ordinary' court or the administrative court.

15 See for instance Asylum Information Database (AIDA), Country report on France from December 2015, available at http://www.asylumineurope.org/reports/country/france, accessed 29 June 2016.

16 As per Article 3 of Directive 2013/33/EU of the European Parliament and of the Council of 26 June 2013 laying down standards for the reception of applicants for international protection oJ L 180, 29 June 6 2013, individuals will be considered as asylum seekers when the 'make an application' for international protection on the territory of a Member State. M. Agier, 'Le Camp de Regroupement de Calais: Retours Sur Une Violence', Médiapart Blog, 26 June 2015, https://blogs.mediapart.fr/edition/openeurope/article/260615/ le-camp-de-regroupement-de-calais-retours-sur-une-violence, accessed 12 March 2016.

18 Akoka \& Clochard 2016; Agier 2014; Prestianni 2014.

19 For a complete overview see Gisti (Groupe d'information et de soutien des immigrées), Les droits des habitants de bidonvilles et squats menacés d'expulsion, http://www.gisti.org/ spip.php?article4826\#chapII2 (Paris : Gisti, 2014).

20 Article 322-1 Code Pénal, Version en vigueur au 10 septembre 2002.

21 Article L. 411-1 Code des procédures civiles d'exécution, Version en vigueur au 4 avril 2017. 
The ordinary court may order expulsions from private terrain, after the illegal occupants have been served with an order to release the premises. ${ }^{22}$ Should the expulsion be authorised, the period for leaving the premises cannot be less than three months or more than one year. ${ }^{23}$

When the terrain belongs to a public body, such as a commune, the terrain may be part of either public or private domain. Here, the ordinary court deals with evictions of private domain (whereby the procedure for private terrain detailed above applies) and the administrative court deals with the public domain. ${ }^{24}$ In the case of the later, the administrative court must decide whether the expulsion measure fulfils the cumulative criteria of urgency and utility. ${ }^{25}$ The urgency criterion is most often measured against public security or public health. ${ }^{26}$ For the utility criterion to be met, it must be proven that the occupation hinders a specific project to operate at the estate or its use in accordance with its purpose, including a public service. ${ }^{27}$

If there are risks to public security, public health or public order, the public body may use his administrative powers to proceed with an expulsion without a court decision. ${ }^{28}$ While no Court order is required in these cases, the legislation specifies that formal notice to leave must have an implementation period of at least 24 hours. ${ }^{29}$

In each of the different proceedings, the expulsion measure must always be proportional, ${ }^{30}$ and fundamental rights, such as the right to private and family life; the right to respect for a home; the principle of human dignity of the human person; and the best interests of the child, must always be upheld.

22 Article L. 411-1 Code des procédures civiles d'exécution, Version en vigueur au 4 avril 2017; Articles 493 and 812 Code des procédures civiles d'exécution, Version en vigueur au 1 janvier 1976; Articles 808 and 809 Code des procédures civiles d'exécution, Version en vigueur au 4 avril 2017 .

23 Article L.412-4 Code des procédures civiles d'exécution, Version en vigueur au 27 mars 2014.

24 Article L. 2111-1 du Code général de la propriété des personnes publiques, Version en vigueur au 1 juillet 2006, states that a terrain belongs to the public domain if it is for the benefit of the general public or if it is assigned to a public service.

25 Article L521-3 Code de justice administrative, Version en vigueur au 1 janvier 2001.

26 See for instance: Tribunal Administratif de Montreuil, 12 avril 2012, $\mathrm{n}^{\circ} 1202325$; Conseil d'Etat, 5 mars 2014, $\mathrm{n}^{\circ} 372422$.

27 Conseil d'Etat, 5 mars 2014, $\mathrm{n}^{\circ} 369607$.

28 Article L. 2212-2 or Article L. 2215-1 of the Code Général des Collectivités Territoriales.

29 Article 38 Loi du 5 mars 2007 sur le droit au logement opposable.

$30 \quad$ Cour d'Appel de Paris, 22 janvier 2015, $\mathrm{n}^{\circ} 13 / 19308$. 


\subsubsection{9 to 2014: The First Traces of the 'policy of invisibilisation'} The Sangatte centre ${ }^{31}$ was run by the Red Cross at the request of the French government from 1999 to $2002 .{ }^{32}$ Created to empty the Calais gardens of the migrants which had settled there, ${ }^{33}$ the centre was initially conceived to be for a period of six months and to house 800 people. ${ }^{34}$ Three years later, it accommodated around two thousand people. Too visible to the public, the Sangatte Centre was closed in 2002. ${ }^{35}$ Most of those who resided in the hangar at the time were officially admitted to the $\mathrm{UK},{ }^{36}$ the rest were forced to wander in the region. In the years after the closure of Sangatte, while persisting in their attempts to reach the UK, migrants set up small informal camps and/or squats in and around Calais. Migrants also resisted the repressive French police who, almost daily, destroyed the settlements and arrested migrants, who were nearly always subsequently released. ${ }^{37}$

In 2009, an Afghan majority of Pachtoune origin organized themselves in a more structured manner to create what is commonly known as the 'Pachtoune jungle'. It was located in a small forest on the outskirts of the city, behind the port of Calais where the ferries leave for the UK. By august 2009, the jungle became a real camp with around 700 inhabitants. ${ }^{38}$ Like Sangatte, the 'Pachtoune jungle' gave visibility to the migration phenomenon occurring in Calais. It was consequently destroyed by the French authorities in September 2009.

With the exception of places of nourishment, migrants often separate themselves throughout their daily lives by country of origin, nationality and/or ethnicity. ${ }^{39}$ "While Afghans (prior to 2009) resided mostly in the forest, other squats and makeshift camps throughout the city hosted other nationalities, such as Egyptians, Palestinians and individuals from the Maghreb." ${ }^{\prime 0}$ Upon

31 The centre received its name from the town within which it was located, Sangatte, approximately nine kilometres away from Calais. It constituted of a hangar situated in the middle of fields and close to the sea.

32 Maller, 'Il y a dix ans, le centre de la Croix-Rouge de Sangatte fermait ses portes', La Voix du Nord (4 November 2012), www.lavoixdunord.fr/region/il-y-a-dix-ans-le-centre-de-la -croix-rouge-de-sangatte-jnaobon804815, accessed 7 May 2016.

33 Akoka \& Clochard 2009.

$34 \quad$ Maller 2012.

35 Akoka \& Clochard 2009.

36 Maller 2012.

37 Prestianni 2014.

38 Ibid.

39 Ibid.

$40 \quad$ Ibid. 
destruction of the Pachtoune jungle, Afghans found other places of settlement in and around Calais.

\section{4: City Camps and Squats}

In July 2014, an eviction took place from a camp situated in the port area, at the terre-plein Darquer (where food was distributed) as well as from three squats. ${ }^{41}$ This was the result of a request of the municipality of Calais to the Lille Administrative Tribunal. The municipality of Calais maintained that the occupation of the terre-plein Darquer constituted an urgent situation affecting public safety and order, but also due to the violation of a convention established between the municipality and the region nord-pas-de-Calais. The Lille Administrative Tribunal authorised these evictions. The juge des référés (president of the court) considered that the inadequate sanitary infrastructures and the pile of waste, partly imputable on the municipality due to its failure to implement material means, undermined public safety. Moreover, the judge found that the interests of the migrants, including all the risks or grievances associated, in cases of evictions, to a dispersion of migrants on the territory without immediate access to alternative housing, did not outweigh the general interest in protecting public safety. ${ }^{42}$

\subsubsection{5 to 2016: A State Township?}

The most recent settlement, destroyed in October 2016, was situated at the outskirts of Calais on an industrial wasteland, ${ }^{43}$ approximately $10 \mathrm{~km}$ away from

41 'Plus de 300 migrants évacués d'un camp à Calais', Le Monde, 2 July 2014, http://www .lemonde.fr/societe/article/2014/07/o2/le-principal-camp-de-migrants-de-calais-en -cours-d-evacuation_4449087_3224.html, accessed 28 September 2016.

Tribunal Administratif de Lille, 27 June 2014, req. no. 1403975 (Commune de Calais,), para 6. In response to this expulsion order, six applicants requested to the ECtHR an interim measure under article 39 of the rules of the court, in order to stay the execution of the expulsion order. In response, the ECtHR asked the French authorities to explain the measures undertaken to ensure the rehousing of the applicants in case of expulsion. According to the ECtHR's press release, the French authorities had set up an emergency system which, amongst others, provided migrants with information about their rights. Moreover, measures allowed migrants to benefit from reception centres and access emergency shelters. Consequently, the ECtHR found that the French authorities had provided sufficient guarantees to the applicants (European Court of Human Rights, Press Release, 2 July 2014).

43 Refugee Rights Data Project, The Long Wait: Filling Data Gaps Relating to Refugees and Displaced People in the Calais Camp, (London: RRDP, 2016) https://passeursdhospitalites. 
the closest supermarket. It combined a state-led day centre, known as the Jules Ferry day centre, the Centre d'Acceuil Provisoire (CAP, temporary welcome centre) and makeshift areas. The isolation of the day centre was the result of a political choice which actively sought to reduce the level of migrant squatting in the city-centre of Calais. ${ }^{44}$ The Jules Ferry day centre was created in 2015 by the French government ${ }^{45}$ to respond to the humanitarian crisis. It aimed to provide Calais migrants one meal a day, daytime showers and toilets and mobile charging. It also provided overnight accommodation for women and children. ${ }^{46}$ In parallel to the creation of the Jules Ferry day centre, seven living places in the city centre of Calais were emptied of their inhabitants and subsequently destroyed, either by use of public force, or by simple 'persuasive measures' to go live in the field adjacent to the centre to receive the benefits provided by the latter. ${ }^{47}$ At that time, local organisations were told that if the migrants settled in the terrain adjoining the Jules Ferry day centre, they would not incur risks of expulsion. ${ }^{48}$ In January 2016, a new CAP was opened at the same spot-a facility comprised of 125 containers each adapted for 12 people, to accommodate around 1,500 migrants. ${ }^{49}$

Preceded by three partial evictions and destructions in September 2015, November 2015 and January 2016, ${ }^{50}$ the French government again exercised force in February 2016 by commanding the occupants 'sans droit ni titre' to leave the southern half of the makeshift camp and proceeded with destroying

files.wordpress.com/2016/04/rrdp_thelongwait.pdf, accessed 12 August 2016 (Dates of the research: 20-26 February).

44 Defender of Rights, Exiles and fundamental rights: the situation in the territory of Calais (Paris: Le défenseur des droits, 2015), p. 10, http://www.defenseurdesdroits.fr/sites/ default/files/atoms/files/20151006-rapport_calais_en.pdf, accessed 14 August 2016.

45 The Jules Ferry day centre had a budget of 10 million euros supplied by the EU, the UK and France (Defender of Rights (n. 45) 9).

46 Defender of Rights 2015, p. 9.

47 Ibid., p. 10.

48 Ibid.

49 M. Baumard, 'Entre les conteneurs et la "jungle", les deux visages du Calais des migrants', Le Monde, 26 January 2016, http://www.lemonde.fr/immigration-et-diversite/ article/2016/o1/26/entre-le-camp-humanitaire-et-la-jungle-les-deux-visages-du-calaisdes-migrants_4853441_165420o.html\#cMwfxgRp6YqciaK4.99, accessed 2 January 2017.

50 Passeurs d'hospitalités, 'Destruction partielle du bidonville:trois précédents déjà.,' Blog: Passeurs d'hospitalités, 14 February 2016 <https://passeursdhospitalites.wordpress. com/2016/02/14/destruction-partielle-du-bidonville-trois-precedents-deja/> accessed 12 August 2016. 
it. ${ }^{51}$ Migrants and civil society organisations asked the juge des référés to stop the expulsion order. They argued that the one-week time-limit left to them before the implementation of the expulsion was insufficient. ${ }^{52}$ They also claimed that there was no danger to public safety. ${ }^{53}$ Finally, the applicants stated that, in conformity with the ECHR, a national judge should verify the proportionality of the measure..$^{54}$ The migrants based their claim on Article 3 and 8 ECHR. They argued that the expulsion order particularly infringes Article 8 on the right to respect private and family life but also on the right to respect for a home. ${ }^{55}$

In contrast, the Prefect claimed that the expulsion order aimed to address public safety and public order. ${ }^{56}$ In that regard, she highlighted the persisting migrant attempts to get on the highway, the regular degradation of property experienced by residents, and the increased altercations between the police and migrants. Moreover, she argued that the applicants cannot rely on the fact that they were not expelled in April 2015 to invoke a right to remain in the area. In arguing this, she merely stated that "la jurisprudence Winterstein qui se borne à appliquer le principe de proportionnalité ne leur confère aucun droit particulier". ${ }^{57}$ In other words, in her view, the ECtHR in the case of Winterstein, merely applies the principle of proportionality which does not imply any special rights for the migrants in this particular case. ${ }^{58}$ The Prefect also stated that the expulsion order aimed at relocating migrants to decent housing and that the housing capacities in the northern parts of the camp and the Centres Accueil et d'Orientation (CAO, or Welcome and Orientation Centre) set up across France were sufficient. CAOs are temporary housing structures ${ }^{59}$ for migrants created in October 2015 in response to the migration crisis and more specifically the expulsions of the Calais camps. The government announced that migrants living in CAOs should specify their goal after one month: apply for asylum in France or leave the country. If a person decides to file for asylum, they will be accompanied in their first asylum request in order to eventually

$5^{1}$ A. Chrisafis, 'France prepares to bulldoze half of Jungle migrant camp', The Guardian, 12 February 2016, www.theguardian.com/world/2016/feb/12/half-jungle-camp-calais-bull dozed-migrants-moved, accessed 25 June 2016.

$5^{2}$ Tribunal Administratif de Lille, 25 Février 2016, req. no. 1601386 (Sharifi and others).

53 Ibid.

54 Ibid.

55 Ibid.

$56 \quad$ Ibid.

57 Ibid. at 3 .

58 Ibid. at 3,7 .

59 These buildings are generally owned or leased by the state to accommodate migrants. 
offer them a place in a Centre d'Accueil de Demandeurs d'Asile (CADA, a reception centre), a much more stable structure adapted to asylum seekers. ${ }^{60}$

The Lille Administrative Tribunal accepted the Prefects claim that the overall aim of the evictions of the southern part of the settlement was to maintain public safety. ${ }^{61}$ Moreover, the juge des référés visited the site on 23 February 2016. The judge noted that the southern zone of the camp was made up of precarious housing including diverse materials and tents and highlighted the complete absence of sanitary facilities, with the exception of waste depositories. It continued by stressing that these facilities, as well as the CAP composed of 125 containers with 1500 places, were present in the northern part of the camp. In view of this close proximity with the Jules Ferry Day Centre, the Lille Administrative Tribunal highlighted the availability of alternative housing in the northern part of the camp. ${ }^{62}$ Moreover, it held that the applicants' circumstances, namely their presence on the site for months and/or years, do not confer upon them any right to retain that irregular situation. ${ }^{63}$ For these reasons, the Tribunal stipulated that the facts of the case did not raise any serious doubts under Articles 3 and 8 ECHR. ${ }^{64}$ The Tribunal excluded from the order structures such as spaces of worship, schools, a library, a shelter reserved for women and children, theatres, and a space dedicated to minors. The Tribunal considered that these structures provided social and cultural services to migrants and did not pose a threat to public security. ${ }^{65}$ As a result, their destruction would be disproportionate. Particularly striking is the failure of the

6o Ministère de l'intérieur and Ministère du logement et de l'habitat durable (2016). Charte de fonctionnement des centres d'accueil et d'orientation (CAO) (July), http://www.gisti .org/IMG/pdf/min_int_logement_2016-07_charte_fonctionnement_cao.pdf, accessed o1 December 2016; The French state set up a website to explain the October 2016 expulsions and camp dismantlement, http://etat-a-calais.fr/laccueil-en-france/, accessed 10 November 2016.

61 Tribunal Administratif de Lille, 25 Février 2016, req. no. 1601386 (Sharifi and autres), para 12 It is estimated that around 80 percent of the individuals who went to the caos intended to make an asylum application in France. As a result, the question of where they would go after the one month period passed was rarely posed. Those who went to the CAOs reluctantly often left voluntarily after one week or two. Forced expulsions from the CAO's at the end of the one month period were limited (not more than 20) and most of these expulsions were individuals to whom the Dublin Regulation applied. In practice there were rarely any returns to the country of origin (contact with Platform d'aide aux migrants).

$62 \quad$ Ibid. at para 10.

63 Ibid.

64 Ibid.

65 Ibid. at para 13. 
Tribunal, in its deliberations, to reflect at all on the one-week time-limit left to the migrants before the implementation of the measure.

On 26 September 2016 President Hollande announced the 'full and final' dismantlement and clearance of the Calais camp on humanitarian grounds. ${ }^{6} 6$ Migrants and civil society organisations again asked the juge des référés to stop the expulsion order. ${ }^{67}$ The applicants used a number of different arguments. They argued that the evacuation of the makeshift camp was going to be executed without an adequate investigation into the effects of such a measure ${ }^{68}$ and that the operation, as presented by the authorities, ran the risk of subjecting individuals to treatments prohibited under Article 3 ECHR. They also pertained that this state interference was neither necessary nor proportionate in the sense of the right to respect private and family life of the inhabitants of the township. In addition, though conceding that the township is precarious, they argued that it constitutes a home for the applicants that should be protected. They asked the state to increase the access to the provisional centres already present in Calais and to the Jules Ferry centre, and to construct new structures. Finally, while the applicants did not, in principle, argue in favour of maintaining the township, they asked the state to consider the life goals of the applicants to join the United Kingdom and therefore to reinforce rehousing options in the region. ${ }^{69}$

The Prefect first argued that the evacuation of the camp is justified by the significant disturbance to public order, both for the local residents and for users of the port, and the existence of violence. The former is linked, as the Prefect argued, to the significant increase in the migrant population in the camp, as well as the increased ethnic conflicts and the deteriorating conditions for women. Finally, she noted the high risk of health issues, also because part of the camp will not allow the migrants to spend the winter in dignified conditions due to the lack of heating, flood risks for tents and shelters, and the risk of fire due to the presence of gas cylinders or gas canisters in tents and shelters for cooking. ${ }^{70}$

66 P. Huguen, “Jungle" de Calais: Hollande promet un démantèlement complet "d'ici la fin d'année", Le Parisien 26 September 2016, http://www.leparisien.fr/politique/migrantsfrancois-hollande-en-visite-a-calais-ce-lundi-matin-26-09-2016-6150763.php, accessed 2 November 2016.

67 Tribunal Administratif de Lille, 18 October 2016, req. no. 1607719 (M. Loay M. et autres), at paras 15,16 .

68 Ibid. at para 3.

$69 \quad$ Ibid. at 4.

$70 \quad$ Ibid. at para 5 . 
The Lille Administrative Tribunal upheld the expulsion. It considered two human rights claims, first on the right not to be subjected to inhuman and degrading treatment, and secondly, on the right to private and family life. It found, in particular, that the reception places and conditions in the cAOs set up across France sufficiently addressed the particular needs of migrants. It also emphasized that public authorities are not required to take into account the choice of migrants regarding their state or place of residence. ${ }^{71}$ The right to respect for a home was examined under the right to respect of private and family life and was rapidly dismissed. Although it indicated that some camp settlements could be considered as constituting a home within the meaning of Article $8 \mathrm{ECHR}$, the reasons discussed under the inhuman and degrading treatment were sufficient to dismiss the claim. ${ }^{72}$

As a result, the camp was completely dismantled at the end of October 2016.

\subsection{Amsterdam}

In Amsterdam, the issue of informal migrant settlements is more recent and strongly intertwined with migrants' protest against the migration regime. In 2012, irregular migrants started mobilizing themselves and established the 'We are here' protest group. The strategy of this group has been to occupy empty pieces of land with tents or to squat empty buildings in order to have a place to stay, but also to be able to live together and to have a place for political, cultural and social events. ${ }^{73}$ Before 2012, irregular migrants in Amsterdam did not collectively protest against their living situation and most of them managed to survive through working on the informal labour market, assistance from relatives or their ethnic community and renting a place to live on the private or informal housing market. ${ }^{74}$

\subsubsection{Dutch Legal Framework for Evictions}

In the Netherlands, squatting is a criminal offence ${ }^{75}$ and squatters can be evicted on the basis of criminal or private law. In both cases, a voorzieningenrechter

$71 \quad$ Ibid. at paras $15,16$.

$72 \quad$ Ibid. at para 17.

73 D. Dadusc, 'Squatting and the undocumented migrants struggle in the Netherlands', in: P. Mudu \& S. Chattopadhyay (eds.), Migration, Squatting and Radical Autonomy: Resistance and Destabilization of Racist Regulatory Policies and B/Ordering mechanisms (Oxford: Routledge, 2016), pp. 275-284.

74 G. Engbersen et al., Illegale vreemdelingen in Nederland. Omvang, overkomst, verblijf en uitzetting (Rotterdam: RISBO Contractresearch BV/Erasmus Universiteit 2002).

75 Article 138a Wetboek van Strafrecht. 
('interim injunction proceedings judge') can examine the proportionality of the eviction beforehand. In private law, the owner of the building can start legal proceedings against the squatters on the basis of tort law and order the eviction, and in criminal law the squatters can start legal proceedings against an announced eviction. ${ }^{76}$ Policy rules of the Public Prosecutor indicate that usually, evictions will be announced at least seven days in advance. ${ }^{77}$

In both kinds of legal proceedings, the framework of review that the judge needs to apply entails that the Dutch legislator has decided that the interest of the owner of the building and/or the general interest of public order and/or the prevention of crime in general have precedence over the interests of squatters and their right to respect for a home. According to the Dutch Supreme Court, the independent judge must examine how the precedence given in abstracto by the Dutch legislator to the interests of public order, the prevention of crime and the protection of rights of others, relates in a concrete case to the principle of proportionality. The starting point in the proportionality assessment is that the owner can dispose of the building in a way that he or she prefers. It will therefore usually be the case that the interests of the owner prevail. Nevertheless, according to the Supreme Court, it cannot be excluded that the interests of squatters (temporarily) outweigh the interest of the owner under particular circumstances. Such particular circumstances should be adduced by the squatter. ${ }^{78}$

\subsubsection{2: Tent Camps}

The 'We are here' movement started protesting and living together in a tent camp in September 2012. A small group of irregular migrants settled in the garden of a church in Amsterdam with the idea of making themselves visible, inspired by an earlier tent camp of rejected asylum seekers in Ter Apel. ${ }^{79}$ Three

76 J. Groenewoud, 'Kraken, hoe zit het nu precies?', 1Journaal Huur \& Verhuur (2011) 3-6.

77 Strafrechtelijke ontruimingen, Staatscourant 2 December 2010, no. 19500. There are four exceptions to this rule: the squatters are suspected to violate the right to respect to a home of other individuals; the squatters are suspected of other serious criminal offences as a result of which the interests of the owner of the building will be seriously affected; in order to prevent a dangerous situation; and on the basis of serious public order concerns. In those four cases, therefore, evictions can take place before the interim injunction proceedings judge has ruled on the case.

78 See eg. Hoge Raad 28 October 2011, ECLI:NL:HR:2011:BQ9880; Hoge Raad 10 December 2013, ECLI:NL:HR:2013:1737.

79 Dadusc 2016; Geschiedenis van wij zijn hier (Amsterdam: Wij zijn hier, 2012-2017), available at: http://wijzijnhier.org/tijdslijn/geschiedenis-van-wij-zijn-hier/, last accessed 29 March 2017. 
weeks later, 25 September 2012, the group settled at a courtyard in AmsterdamWest and grew considerably.

The Mayor of Amsterdam initially allowed the tent camp, as part of the demonstration, even though it was in violation with local regulations. Permission was conditional on the tent camp not getting any bigger; safeguarding hygienic and fire safety conditions, and on not having children living in the camp. On 16 November 2012, however, the Mayor ordered the migrants to end the demonstration and the tent camp and to leave the courtyard by 23 November at the latest, after which the migrants would be evicted from the camp with the use of force if necessary. The reasons for this decision were that the number of people spending the night in the tent camp had increased in violation with the conditions, that there were serious concerns about the physical and mental health of the migrants living in the tent camp and that there were serious public health and public order risks. ${ }^{80}$

The migrants went to court and asked for a (provisional) stay of execution of the Mayor's decision. They argued that there were not sufficient reasons to deny them the right to demonstrate. The judge, applying the Dutch constitutional framework on the right to demonstrate, refused this request on the basis of public health and public order risks, taking into account that the Mayor had had numerous conversations with the migrants, offered them temporary basic shelter in a number of other municipalities and announced that the demonstration, without the tent camp, could be continued at another location. ${ }^{81}$

\subsubsection{2 to 2013: Squatting}

After the eviction of the tent camp, the migrants were assisted by the squatters movement of Amsterdam in occupying an empty church (Vluchtkerk). With the agreement of the owner, they managed to stay there for six months. Since then, different buildings were squatted, and eventually subjected to eviction procedures: empty office spaces (Vluchtflat, Vluchtkantoor); an empty garage (Vluchtgarage); a former hospital etc. ${ }^{82}$

8o Letter of the Mayor of Amsterdam, mr. Van der Laan, to the city council, 7 November 2012, available at http://content1d.omroep.nl/urishieldv2/l27m6302ea3048b4d12doo582c 35a6000000.927db64d3e9a5845ao1fo8da4beacb35/nos/docs/071112_notweg.pdf, accessed 16 November 2016, and Letter of the Mayor of Amsterdam, mr. Van der Laan, to the lawyer of the 'We are here' group, mr. Wijngaarden, 16 November 2012, available at: http://www .prakkendoliveira.NL/user/file/121116_-_besluit_b\&w_amsterdam_ontruiming_tenten kamp_(wij_zijn_hier).pdf, accessed 28 September 2016.

81 District Court Amsterdam, 28 November 2012, ECLI:NL:RBAMS:2012:BY4471.

82 Dadusc 2016; Wij zijn hier 2012-2017. 
Information on the website of 'We are here' shows that there have been different court proceedings about evictions from these places, and that in all court cases, the interests of the owner have prevailed over the interests of the migrants. In only two cases were judgments published. ${ }^{83}$ In these cases, the judges considered the unlawfulness of staying in the buildings as a decisive factor, or one of the most important factors.

In a judgment of 1 August 2013, about the eviction of 25 Somalian migrants from a privately owned building, squatted in July, the judge did refer to the right to respect for a home as protected by Article $8 \mathrm{ECHR}$. However, the court dealt with this right in a very limited way. The judge held that Article 8 only exceptionally provides protection in horizontal relationships and that in this case the interests of the private owner outweighed the migrants' right to a home that they had unlawfully established. The judge did not discuss any particular circumstance of the case but just stated, very generally, that the interests of the owner in this case weighed more heavily. ${ }^{84}$

In the judgment about the expulsion of the Vluchtgarage, the Amsterdam Court of Appeal held that Article 8 ECHR does not imply that the state should provide everybody with a home. It further considered that the interests of the city of Amsterdam, owner of the garage, outweighed the interests of the migrant squatters. In reaching this conclusion, the Court took into account that the migrants lived unlawfully in the garage and that their presence in the garage could not be regularized. Another relevant consideration for the Court was the availability of a basic night shelter for the migrants in Amsterdam (the 'bed, bath and bread facilities, see below). ${ }^{85}$

The migrants lodged an appeal against this judgment with the court of cassation (the supreme court, Hoge Raad). They argued, amongst other things, that the Court of Appeal had not taken into account all relevant circumstances in its proportionality analysis. ${ }^{86}$ This appeal was dismissed without any substantive discussion, since the grounds of appeal did not, according to the court, necessitate answering questions in the interest of legal uniformity or development of the law. 87

83 See footnote 9 above for the database and search terms that have been used.

84 District Court Amsterdam, 1 August 2013, ECLI:NL:RBAMS:2013:4804.

85 Court of Appeal Amsterdam, 31 March 2015, ECLI:NL:GHAMS:2015:1121. In this procedure, the lower judge had prohibited the eviction during the winter, because of the precarious living conditions for migrants who had to sleep on the streets during the winter, see District Court Amsterdam, 20 February 2015, ECLI:NL:RBAMS:2015:847.

86 See conclusion of the Attorney General in this case (8 July 2016, ECLI:NL:PHR:2016:839).

87 HR 7 October 2016, ECLI:NL:HR:2016:2281. 


\subsubsection{3: Temporary Governmental Shelter for Some}

As from December 2013, the municipality of Amsterdam offered temporary shelter to a circumscribed number of migrants of the 'We are here' group. This was a pilot project and was approved by the secretary of state responsible for migration affairs. ${ }^{88}$ The central government had placed an empty former prison at the disposal of the municipality of Amsterdam for this project. In this former prison (at the Havenstraat, called Vluchthaven) the municipality of Amsterdam provided 128 irregular migrants ${ }^{89}$ with shelter, some pocket money and support for a period of six months. The purpose of this pilot project was to provide the migrants with the possibility to work on their future (either in the Netherlands via a renewed application for a residence permit, or in their country of origin or a third country) without the daily concern for shelter and food.

After six months, the migrants had to leave the Vluchthaven. Only migrants who were identified by the health authorities as particularly vulnerable and migrants who were willing to return to their country of origin were offered temporary alternative accommodation. When the migrants refused to leave the Vluchthaven, court proceedings were initiated by the municipality of Amsterdam (that was obliged to make the building at the disposal of the central government again). The Court held that the migrants were not entitled to be accommodated in the Vluchthaven; the shelter there was offered by the municipality on a voluntary basis, not on the basis of a legal obligation on the part of the authorities. The remainder of the judgment concentrated on the question whether all migrants living in the Vluchthaven were entitled to alternative accommodation. The Court concluded that this was not the case and ordered the eviction of the building within four days. ${ }^{90}$

According to the secretary of state, the results of the pilot project were disappointing, since a large group of migrants had not been willing to cooperate in their return to their country of origin. ${ }^{91}$ The evaluation by the municipality

88 Kamerstukken II, 2013/14, 19637, no. 1765.

89 Initially, the offer for temporary shelter was only given to 159 migrants that had registered themselves with the authorities pending their stay at the Vluchtkerk. In Feburary 2014, shelter in the Vluchthaven was offered to 26 other migrants who stayed in the Vluchtkantoor in December 2013 and were screened by health authorities. Not all migrants accepted the offer (some got in the meantime a residence permit, left the country, or were put in detention). See 'Evaluatie Vluchthaven Amsterdam. Periode december 2013-juni 2014', bijlage bij Kamerstukken II, 2013/14, 19637, nr. 1866.

90 District Court Amsterdam, 20 June 2014, ECLI:NL:RBAMS:2014:3532 and District Court Amsterdam, 4 July 2014, ECLI:NL:RBAMS:2014:3952.

$91 \quad$ Kamerstukken II, 2013/14, 19637, nr. 1866. 
shows that two migrants had returned during the project and eight individuals were considering whether to return. ${ }^{92}$

\subsubsection{4 to Present: Bed, Bath and Bread}

After the temporary pilot project in the Vluchthaven, the migrants continued squatting empty buildings and the authorities kept on evicting them. ${ }^{93}$ Influenced by a decision of the European Committee of Social Rights on a complaint lodged by the Conference of European Churches against the Netherlands, ${ }^{94}$ the municipality of Amsterdam decided in December 2014 to provide basic shelter (a bed in a dorm), food (dinner and breakfast) and sanitary facilities (a shower) to all irregular migrants living in Amsterdam. These 'bed, bath and bread' facilities were only available from 4 pm until 9 am. Every morning, the migrants had to leave the facilities again with all their belongings. The migrants disliked these facilities and continued living in squatted buildings. The facilities were, however, deemed sufficient by the Court of Appeal of Amsterdam, which was one of the decisive elements in the judgment upholding the eviction from the Vluchtgarage (see above). ${ }^{95}$

In April 2015, the government announced its intention to enter into a new agreement with the municipalities of the Netherlands. The government sought to limit the provision of the municipal bed, bath and bread facilities to only a couple of weeks. After that period, irregular migrants would only be eligible for a particular state-run shelter in a remote place where freedom of movement would be restricted, provided that they are willing to cooperate with their return. ${ }^{96}$ While this conditional form of basic shelter was held to meet the minimum standards of Articles 3 and $8 \mathrm{ECHR}$ by the highest administrative courts of the Netherlands, ${ }^{97}$ the government has not yet been able to reach agreement with the municipalities.

92 'Evaluatie Vluchthaven Amsterdam. Periode december 2013-juni 2014', bijlage bij Kamerstukken II, 2013/14, 19637, nr. 1866.

93 Geschiedenis van wij zijn hier 2012-2017.

94 European Committee of Social Rights (2015), no. 90/2013 (Conference of European Churches (CEC) v. the Netherlands).

95 District Court Amsterdam, 31 March 2015, ECLI:NL:G HAMS:2015:1121.

96 Kamerstukken II, 2015/16, 19637, nr. 1994.

97 Administrative Jurisdiction Division of the Council of State, 26 November 2015, ECLI: NL:RVS:2015:3415, JV 2016/17; Central Appeals Tribunal 26 November 2015, ECLI:NL: CRVB:2015:3834, JV 2016/19; Central Appeals Tribunal, 26 November 2015, ECLI: NL:CRVB:2015:3803; and Central Appeals Tribunal, 26 November 2015, ECLI:NL: CRVB:2015:4093. 


\subsection{Features of the French and Dutch Interventions}

Although the cases of Calais and Amsterdam are considerably different, they share a number of relevant characteristics. The foregoing analysis shows that in both cities, migrants without authorisation to stay in the territory of the country, made their unlawful presence and rightlessness in the country visible by living in makeshift camps and squatted buildings. In both cities, the authorities reacted with repeated evictions and destruction, but ultimately also by providing some alternative forms of basic shelter.

While migrants often decided themselves to set up their tents at a particular place or to squat a particular building, the examples of Calais and Amsterdam show that there has sometimes been quite some government involvement in the establishments of camps or the occupation of a building. In Calais, the Red Cross ran from 1999 to 2002 a centre for migrants at the request of the French government, and the location of the most recent camp was the result of the opening of the Jules Ferry day centre and instructions from the authorities to move in the land adjoining it. ${ }^{98}$ In Amsterdam, a group of migrants were offered temporary shelter in an empty prison by the local authorities, with explicit permission of the central authorities. Hence, in both cities migrants have lived in buildings and places that have, to some extent, been designated by authorities.

Migrants have often filed lawsuits against eviction and destruction concerning their makeshift camps or squats. Published case law on these evictions in Amsterdam and Calais revealed judges applying different legal frameworks of review, usually at the instigation of the migrants. In one case, the framework of review of the right to demonstrate was applied, whereas in other cases the central question was whether the government was under a positive obligation to provide the migrants with decent living conditions, and, if so, whether the living conditions of the migrants (in alternative forms of shelter) were adequate. With regard to evictions from squats, the regular framework of review that already existed in domestic law on squatting was used. In such cases, the judges apply a proportionality test in which the unlawfulness of the occupation in combination with the interest of safeguarding public order generally outweighs the individual interests of migrants. Domestic case law demonstrates that under these different frameworks of review the numerous camp and squat evictions and dismantlements have been systematically upheld.

In the remainder of this paper, we examine whether the framework of review that has been developed by the ECtHR on Article 8 ECHR's right to respect for a home is applicable to eviction and dismantlement of makeshift 
camps and squats and to what extent this framework of review is reflected in the domestic case law.

\section{Article 8 ECHR}

Home is where the heart is. ${ }^{99}$

Article 8 of the European Convention on Human Rights is well known in migration law for the protection it offers to family and private life. Besides these two important personal interests, Article 8 also provides the right to respect for a home. Interpreted by the Court as an autonomous concept, the meaning of 'home' under Article 8 does not depend on classification under domestic law. ${ }^{100}$ In this section, we identify the meaning attached by the Court to the term 'home' in Article 8 and sketch the legal framework for testing interferences with negative obligations of the state under the right to respect for a home. This enables us to examine how the domestic case law discussed in section 3 relates to this framework of review in section 5 of this paper.

\subsection{Interference with the Right to Respect for a 'Home'}

In its standard phrase on the meaning of 'home', the Court places the factual circumstances, namely 'the existence of sufficient and continuous links with a specific place'101 at the centre of the deliberations.

Since it depends on factual circumstances, the concept of 'home' is, for example, not limited to premises which are lawfully occupied or which have been lawfully established.102 The Court has explicitly ruled that it also applies to illegally established, makeshift houses, even if these houses do not meet the relevant construction requirements and lack sewage and sanitary facilities. ${ }^{103}$

The links with a specific place should be sufficiently strong. In cases of ongoing or recent occupation, this test is generally met. In cases about future or

99 Ancient saying, reported at least as early as 1847, in J.C. Neal, 'Singleton Snippe. Who Married for a Living', Graham's Magazine (1847) at 166: 'Home is where the heart is; and Snippe's heart was a traveler — a locomotive heart, perambulating; and it had no tendencies toward circumscription and confine', https://en.wikiquote.org/wiki/Home, accessed 5 October 2016.

100 Winterstein and others $v$ France Application No 27013/07, Merits, 17 October 2013, para 141.

101 Ibid.

102 Ibid.

103 Yordanova and others $v$ Bulgaria Application No 25446/o6, Merits, 24 April 2012. 
past occupation, however, this test functions as an important threshold. For example, merely planning to build a house for residential purposes on a property is not enough in order to be able to argue that the property constitutes a 'home' within the meaning of Article 8. ${ }^{104}$

The links with a specific premise should also be sufficiently stable. In a case where the applicant had lived in a hotel room for less than a month, the Court had 'significant doubts over whether or not the applicant's links with the hotel room were sufficient and continuous enough to make it his "home". ${ }^{105}$

The Court generally states that 'the loss of a dwelling is a most extreme form of interference with the right to respect for one's home.'106 Actual loss of the home is not always required, threat of expulsion may also constitute an 'interference' for the Court. For example, an obligation to vacate a flat amounts to an interference with the right to respect for a home even though the judgment ordering the eviction has not yet been executed.107 Also, a judicial sale (i.e. legal deprivation) of someone's home should be seen as an interference, even though this only brings about a change of ownership and not a change in the actual living situation, if it is a necessary pre-condition for an eviction (factual deprivation $)^{108}$ or when it cannot be excluded that the people concerned will be required to vacate their home. ${ }^{109}$

\subsection{Justifications of Interference}

An interference with the right to respect for a home, for example by ordering an eviction from a building or a piece of land may be justified if it is in

104 Loizidou v Turkey Application No 15318/89, Merits, 18 December 1996. The same is true with regard to a house that the applicant left more than 20 years ago, when she was two years old, even though she claims that this house is still regarded as the family house (Demopoulos and Others $v$ Turkey Application Nos 46113/99, 3843/02, 13751/02, 13466/03, 10200/04, 14163/04, 19993/04, 21819/04, Admissibility, 1 March 2010; see for another example of past occupation: Andreou Papi v Turkey Application No 16094/90, Merits, 22 September 2009, para 54).

105 O'Rourke $v$ UK Application No 39022/97, Admissibility, 26 June 2001.

106 Winterstein and others $v$ France Application No 27013/07, Merits, 17 October 2013; See also Cosic v Croatia Application No 28261/o6, Merits, 5 June 2009, para 22.

107 Cosic v. Croatia Application No 28261/o6, Merits, 5 June 2009, para 18; See also Vrzic v Croatia Application No 43777/13, Merits, 12 July 2016, para 59.

108 Zehentnerv Austria Application No 20082/02, Merits, 16 July 2009, para 54; Vrzic v Croatia Application No 43777/13, Merits, 12 July 2016, para 59.

109 Keveling and Legerstee $v$ The Netherlands Application No 31717/96, Admissibility, 10 September 1997. 
accordance with the law, if it serves one of the legitimate aims laid down in the second paragraph of Article 8 and if it is necessary in a democratic society.

\subsubsection{Legality}

An interference may only be justified if it is in accordance with the law. The Court has made clear that the term 'law' should be interpreted broadly. It can refer to both statutory law and unwritten (judge made) law, to domestic law, EU law or international law. ${ }^{110}$ For establishing whether an interference in is accordance with the law, the Court has developed three main conditions in its case law. First, there should be a basis in the law. The Court is reluctant to examine whether domestic law has been interpreted or applied correctly, since this function belongs primarily to domestic judicial authorities. However, ' $[w]$ hile the Court is not in a position to substitute its own judgment for that of the national courts and its power to review compliance with domestic law is limited, it is the Court's function to review the reasoning adduced by domestic judicial authorities from the point of view of the Convention'.11

The other two conditions are about the quality of the law: the law should be accessible and sufficiently precise, i.e. it should be possible to have an indication adequate in the circumstances of the legal rules applicable to a given case' and 'if need be with appropriate advice - to foresee, to a degree that is reasonable in the circumstances, the consequences which a given action may entail.'112 The latter condition entails that the legal basis should not provide wholly general and unfettered discretion to the authorities; the limits of discretion should be clear. ${ }^{113}$

The legality condition has been described as 'a crucial interpretive device to condemn national measures under Article 8. ${ }^{\prime 14}$ In eviction cases, however,

110 F.G. Jacobs, R.C.A. White \& C. Ovey, The European Convention on Human Rights, 5 th edition (Oxford: Oxford University Press, 2010), p. 313; D.J. Harris, M. O’Boyle \& C. Warbrick, Law of the European Convention on Human Rights, 2nd edition (Oxford: Oxford University Press, 2009), p. 344.

111 Slivenko v Latvia $[G C]$ Application No 48321/99, Merits, 9 October 2003, para 43, 115 .

112 These two conditions have been formulated by the Court for the first time in the Sunday Times case (ECtHR, 26 April 1974, no. 6538/74, para 49).

113 Harris, O'Boyle \& Warbrick 2009, p. 346.

114 P. van Dijk, F. van Hoof, A. van Rijn \& L. Zwaak (eds), Theory and Practice of the European Convention on Human Rights, 4th edition (Antwerp: Intersentia, 2006), p. 338. 
examples of cases in which the Court concludes that the interference was not in accordance with the law are scarce. ${ }^{115}$

\subsubsection{Legitimacy}

A second condition that needs to be fulfilled before an interference may be justified is that the interference should be in the interests of one of the legitimate aims laid down in the second paragraph of Article 8 ECHR: 'national security, public safety or the economic well-being of the country, for the prevention of disorder or crime, for the protection of health or morals, or for the protection of the rights and freedoms of others'. This condition entails that the state authorities that interfere with Article 8 ECHR, should identify the purposes of this interference. Since the aims that have been summarized in article 8(2) are formulated very generally and broadly, the Court very rarely finds a violation of this condition. ${ }^{116}$ This is also true for eviction cases. ${ }^{117}$

\subsubsection{Necessity}

The interference should not only be provided for by law, and in the interest of a legitimate aim, but it should also be considered 'necessary in a democratic society'. For the Court, this means the interference must address a 'pressing social need'. In particular, the relationship between the interference and its legitimate objectives must be proportional. States are given a margin of appreciation in this regard because the Court finds that State's 'direct and continuous contact with the vital forces of their countries' makes them, in principle, more equipped 'to evaluate local needs and conditions'. ${ }^{118}$ This holds particularly true in social and economic spheres such as housing. ${ }^{119}$ Nevertheless, this margin of appreciation will vary according to the right at stake, its importance for the individual and the nature of the activities restricted, as well as the nature of the aim pursued by the restrictions. ${ }^{\prime 20}$ The Court has stressed that the scope of the margin of appreciation is lowered when a 'key right' like article 8 is at

115 See, e.g. Prokopovich v Russia Application No 58255/oo, Merits, 18 November 2004. In Kryvitska and Kryvitskyy v Ukraine Application No 30856/03, Merits, 2 December 2010 the Court was critical on the foreseeability (para 48), but did not separately conclude on it.

116 Van Dijk, Van Hoof, Van Rijn \& Zwaak 2006, p. 340.

117 S. Fick \& M. Vols, 'Best Protection Against Eviction? A Comparative Analysis of Protection Against Evictions in the European Convention on Human Rights and the South African Constitution', 3(1) European journal of comparative law and governance (2016) 40-69.

118 Yordanova and others v Bulgaria Application No 25446/o6, Merits, 24 April 2012, para 118.

119 Ibid. at para $118(\mathrm{i})$.

120 Ibid. 
stake, which is of 'central importance to the individual's identity, self-determination, physical and moral integrity, maintenance of relationships with others and a settled and secure place in the community'.121

In determining whether the State has remained within its margin of appreciation in eviction cases, the procedural safeguards available to the individual are especially material. The Court has formulated as one of its general principles in eviction cases that '[s]ince the loss of one's home is a most extreme form of interference with the right to respect for the home, any person at risk of an interference of this magnitude should in principle be able to have the proportionality and reasonableness of the measure determined by an independent tribunal in the light of the relevant principles under Article 8, notwithstanding that, under domestic law, he has no right of occupation. ${ }^{122}$ This means, among other things, that if the applicant brings forward relevant arguments concerning the proportionality of the interference, the domestic courts should examine them in detail and provide adequate reasons. ${ }^{123}$ The mere possibility of obtaining judicial review of the administrative decision causing loss of a home is not enough; the Court has stressed that the person concerned must be able to challenge that decision on the ground that it is disproportionate in view of his or her personal circumstances. ${ }^{124}$ This can normally only be examined case by case. ${ }^{125}$

It is possible to deduce a number of relevant factors form the ECtHR's case law for domestic courts to take into account when deciding on the proportionality in eviction cases. First of all, it is relevant whether the home was established lawfully or not. In Chapman, ${ }^{126}$ a case on a complaint by a traveller

121 Ibid. at para $118(\mathrm{ii})$.

122 Ibid. at para 118; McCann v the United Kingdom Application No 19009/04, Merits, 13 May 2008, para 50; Kay and Others $v$ the United Kingdom Application No 37341/06, Merits, 21 September 2010, para 67 at 68 and 74; Orlić v Croatia Application No 48833/o7, Merits, 21 June 2011, para 65 .

123 Yordanova and others v Bulgaria Application No 25446/o6, Merits, 24 April 2012; ECtHR 24 April 2012, para 118.

124 Ivanova and Cherkezov Application No 46577/15, Merits, 21 April 2016, para 53.

125 Ivanova and Cherkezov Application No 46577/15, Merits, 21 April 2016, para 54.

126 Chapman $v$ The United Kingdom Application No 27238/95, Merits, 18 January 2001. Similar cases decided on the same date and containing the same observations of the Court are Beard $v$ the United Kingdom Application No 24882/94, Merits, 18 January 2001; Coster v the United Kingdom Application No 24876/94, Merits, 18 January 2001; Jane Smith $v$ the United Kingdom Application No 25154/94, Merits, 18 January 2001; and Lee v the United Kingdom Application No 25289/94, Merits, 11 February 2013. 
against the refusal of planning permission to station caravans on her own land, the Court held:

If the home was lawfully established, this factor would self-evidently be something which would weigh against the legitimacy of requiring the individual to move. Conversely, if the establishment of the home in a particular place was unlawful, the position of the individual objecting to an order to move is less strong. ${ }^{127}$

In the recent case of Ivanova and Cherkezov ${ }^{128}$ the Court summarized the relevant factors when it comes to demolitions of illegal constructions:

The factors likely to be of prominence in this regard [...] are whether or not the home was established unlawfully, whether or not the persons concerned did so knowingly, what is the nature and degree of the illegality at issue, what is the precise nature of the interest sought to be protected by the demolition, and whether suitable alternative accommodation is available to the persons affected by the demolition. [...] Another factor could be whether there are less severe ways of dealing with the case; the list is not exhaustive. ${ }^{129}$

The relevance of availability of alternative accommodation also stems from the early Chapman case, in which the Court held that " $\mathrm{t}]$ he more suitable the alternative accommodation is, the less serious is the interference constituted by moving the applicant from his or her existing accommodation. ${ }^{130}$ The evaluation of the suitability of alternative accommodation should involve a consideration of, on the one hand, the particular needs of the person concerned and, on the other, the rights of the local community. ${ }^{131}$ Alternative accommodation should be promptly available. In Tuleshov and Others, the Court considered the eviction disproportionate by reason of the huge delay in offering alternative housing to the applicants. ${ }^{132}$ At the same time, the Court usually stresses that

127 Ibid. at para 102. See also Winterstein and others $v$ France Application No 27013/o7, Merits, 17 October 2013 .

128 Ivanova and Cherkezov v. Bulgaria Application No 46577/15, Merits, 21 April 2016.

129 Ibid. at para 53.

130 Ibid. at para 103.

131 Winterstein and others v France Application No 27013/o7, Merits, 17 October 2013, para 148.

132 Tuleshov and Others $v$ Russia Application No 32718/02, Merits, 24 May 2007, para 53. 
Article 8 does not recognize a right to be provided with a home. ${ }^{133}$ As a result these cases do not de facto imply a self-standing right for evicted persons to be re-housed. Instead these cases imply that the state should explicitly consider the possibilities for alternative accommodation, or the risk of becoming homeless, when taking a decision to evict. ${ }^{134}$

The Yordanova case provides a good example of (other) relevant factors that need to be taken into account. This case is about a mass eviction of Roma who for many years had occupied land illegally and lived in self-constructed buildings, without sewage or plumbing, which they never sought to regularize. This case is interesting because of the factual similarities with the situation of some of the migrants evictions in Amsterdam and Calais (i.e. eviction from unlawful occupation with rather deplorable living conditions), but also because the Court, after having established that no proportionality analysis had been carried out by the domestic authorities and judges, shows what a proper proportionality analysis should entail. ${ }^{135}$ In this case, the Court starts with stressing the relevance of a long period of de facto toleration and of the eviction of a whole community. It distinguishes such cases from 'routine cases of removal of an individual from unlawfully occupied property', since the authorities' inactivity has resulted in the applicants' developing strong links with the area in which they were living and building a community life there. ${ }^{136}$ In Winterstein, when summarising the Yordanova case, the Court labelled this fact as 'highly pertinent'. 137

Another factor given a lot of weight by the Court in Yordanova was the underprivileged status of the applicants' group. Being Roma, the Court identified the applicants as 'an outcast community and one of the socially disadvantaged groups'. This disadvantaged position of the social group to which the applicants belong should have been taken into consideration in the proportionality assessment, according to the Court, e.g. when considering alternative

133 Chapman $v$ The United Kingdom Application No 27238/95, Merits, 18 January 2001, para. 99; Yordanova and others v Bulgaria Application No 25446/o6, Merits, 24 April 2012, para. 130.

134 A. Remiche, 'Yordanova and Others v Bulgaria: The Influence of the Social Right to Adequate Housing on the Interpretation of the Civil Right to Respect for One's Home', 12(4) Human Rights Law Review (2012) 787-800.

135 Ibid. See also the blogpost of L. Peroni \& A. Timmer, 'Roma Evictions Stopped in Strasbourg: 8 May 2012, Yordanova e.a. v. Bulgaria', Strasbourg Observers, available at: https://strasbourgobservers.com/2012/05/08/roma-evictions-stopped-in-strasbourg -yordanova-e-a-v-bulgaria/\#more-1587.

136 Yordanova and others $v$ Bulgaria Application No 25446/o6, Merits, 24 April 2012, para 121.

137 Winterstein and others $v$ France Application No 27013/07, Merits, 17 October 2013, para 150. 
approaches to dealing with the unlawful settlements. ${ }^{138}$ Even if eviction is considered to be necessary, this factor should be a weighty factor in deciding on its timing, modalities and, if possible, arrangements for alternative shelter. ${ }^{139}$ The same approach was adopted by the Court in the more recent Winterstein case. ${ }^{140}$ In this latter case, the Court emphasized that even though Article 8 does not include a right to be provided with a home, this can be different in the specific circumstances of the case, especially in case of a long history of residence and the community they had formed. In this regard, the Court referred to a finding of the European Committee of Social Rights on the insufficient number of adapted housing solutions for sedentarized travellers in France being a violation with the European Social Charter. ${ }^{141}$

The cases discussed so far all concern instances where the applicants were living on state-owned land or in state-owned buildings. The case law of the Court suggest that the framework of review might be somewhat different if another private interest is at stake. The case of $\mathrm{Vrzic}^{142}$ concerned the enforcement of a debt through the sale of the applicants' house. The Court attached particular weight in this case to the fact that the other parties in the enforcement proceedings were either a private individual or private enterprises; namely a bank and a company. In such cases, the Court examines whether the decision-making process leading to measures of interference was fair and was such as to afford due respect to the individual interests safeguarded by Article $8,{ }^{143}$ or, in other words, whether the authorities, including domestic courts, 'acted arbitrarily or unreasonably, or failed to discharge their obligation to strike a fair balance between the respective interests. ${ }^{144}$ This means that the Court leaves states a large margin of appreciation is such cases. The Court has been criticized, for example, for allowing domestic courts to have an exceptionally narrow view of landlords' own need of their premises which results

138 In this case the Court mentions as possible alternative approaches: 'legalising buildings where possible, constructing public sewage and water-supply facilities and providing assistance to find alternative housing where eviction is necessary' (at para. 125).

139 Yordanova and others $v$ Bulgaria Application No 25446/o6, Merits, 24 April 2012, para 129, 132 and 133 .

140 Winterstein and others $v$ France Application No 27013/07, Merits, 17 October 2013, para 160.

141 Ibid. at para 165.

142 Vrzic v Croatia Application No 43777/13, Merits, 12 July 2016.

143 Zehentnerv Austria Application No 20082/02, Merits, 16 July 2009, para 58; Zrilićv Croatia Application No 46726/11, Merits, 3 October 2013.

144 Velosa Barreto v Portugal Application No 18072/91, Merits, 21 November 1995, para 30. 
in tenants being overprotected. ${ }^{145}$ The Vrzic case further shows that a relevant factor for the Court in these cases is whether the persons under threat of eviction explicitly and voluntary entered into an agreement which stipulates eviction as one of the consequences for violating contractual obligations. ${ }^{146}$

\section{Article 8 ECH R Framework of Review: An Added Value for Domestic Case Law?}

Due to the Court's autonomous interpretation, makeshift camps and squats in Amsterdam and Calais qualify as 'homes' within the meaning of article 8 ECHR if the migrants have a sufficient stable link with the place. Arguably, if they have lived in a squat or camp for a couple of months, this threshold has been met. The fact that the settlements are, to a certain extent, established unlawfully and have not been regularized does not mean that the safeguards of Article 8 ECHR do not apply. ${ }^{147}$ The Court's case-law makes equally clear that (threats of) evictions and dismantlement are interferences. In our view, therefore, the framework for testing evictions and dismantlements against article 8 ECHR as developed in the case law of the Court is a relevant and useful framework of review and should be used to evaluate the legitimacy of evictions and destructions of informal migrants' settlements. The aim of this section is to examine to what extent this framework of review is reflected in the domestic case law discussed in section 3 .

In the domestic case law as discussed in section 3, article $8 \mathrm{ECHR}$ is rarely mentioned. ${ }^{148}$ This is partly caused by the absence of references to it by the (legal representatives of the) migrants, possibly caused by unfamiliarity with the correct legal framework. Moreover, even when the right to respect for a home of Article 8 ECHR is referred to, the relevant cases identified and discussed in section 4 of this paper are not mentioned in any of the cases concerning the migrants' evictions in Amsterdam and Calais (save for a Prefects claim

\footnotetext{
145 A. Carroll, The International Trend Toward Requiring Good Cause for Tenant Eviction: Dangerous Portents for the United States?', 38(2) Seton Hall Law Review (2008) 427-480 at 477 .

146 Vrzic v Croatia Application No 43777/13, Merits, 12 July 2016, para 70, 71.

147 Yordanova and others v Bulgaria Application No 25446/o6, Merits, 24 April 2012 and Winterstein and others $v$ France Application No 27013/07, Merits, 17 October 2013.

148 And if Article $8 \mathrm{ECHR}$ is mentioned, this does not always concern the right to respect for a home. In one case, the right to respect to a home under article 8 is mentioned within the scope of the right to respect for private and family life, and not separately (supra section 3$)$.
} 
in one of the French cases that applicants cannot rely on the fact that they were not expelled in the past to invoke a right to remain in the area through the Winterstein case-law ${ }^{149}$ ). This would not necessarily be problematic if the relevant factors and rules established in this case law were nevertheless applied by the domestic courts. We argue, however, that that is not the case.

As seen in section 3, some of the domestic case law has the tendency to focus its attention on the question of whether the migrants are entitled to housing. This concerns the state's possible positive obligation under Article 8 ECHR. The question whether irregular migrants are entitled to shelter is, however, different from the question of whether the government is entitled to actively demolish irregular migrants' homes or evict irregular migrants from their homes. This latter question concerns the state's negative obligations under Article 8 ECHR. A response to this question requires an assessment on whether the interference with the right to respect for a home is justified, which is different from assessing the state's positive obligations. After all, alleged violations of positive obligations are usually not evaluated under the second paragraph of Article 8. Moreover the Court consistently stresses that 'the scope of any positive obligation to house the homeless must be limited', ${ }^{150}$ since 'whether the State provides funds to enable everyone to have a home is a matter for political not judicial decision. ${ }^{\prime 151}$ Hence, the Court leaves states much room for deciding on the provision and allocation of housing. With regard to evictions, however, the case law of the Court shows that states have to meet a number of important conditions.

Firstly, evictions should have a clear legal basis, with limited discretion for the authorities. In case of evictions from a privately-owned property, the legal basis in domestic law will most probably be sufficient. However, with regard to evictions from state-owned property, especially where the authorities have initially designated a particular location as a place where migrants could live, this may be different. In domestic case law, this important first criterion is not always explicitly dealt with. If, however, a domestic legal basis is not available, or if it leaves too much discretion to the authorities, an eviction will always, under all circumstances, result in a violation of Article 8 ECHR. The legality

\footnotetext{
149 Tribunal Administratif de Lille, 25 février 2016, req. no. 1601386 (Sharifi \& autres), at 3, 7 .

150 O'Rourkev the United Kingdom Application No 39022/97, Decision, 26 June 2001; Yordanova and others v Bulgaria Application No 25446/o6, Merits, 24 April 2012, para. 130; Strzelecka v Poland Application No 14217/10, Decision, 2 December 2014, para. 49.

151 Chapman $v$ The United Kingdom Application No 27238/95, Merits, 18 January 2001, para. 99; Strzelecka v Poland Application No 14217/10, Decision, 2 December 2014, para. 49; Kashchukv Ukraine Application No 5407/06, Decision, 10 May 2016, para. 53.
} 
criterion is, therefore, a very important first step in a review of an eviction under Article $8 \mathrm{ECHR}$ that domestic judges should always explicitly deal with.

Secondly, a proportionality assessment which deals with all relevant elements, should be applied in every case. This is first and foremost a procedural safeguard. The ECtHR requires that domestic courts examine relevant arguments concerning the proportionality of the interference in detail and provide adequate reasons, on a case by case basis. However, the ECtHR case law, e.g. the Yordanova and Winterstein cases, also provides substantive protection, since the Court provided guidance on how the proportionality assessment should be carried out. From these cases, it follows for example that significant weight must be attached to long lasting presence of persons in a particular area, and the ties that have been developed. Even though (un)lawfulness of the establishment of the home is a relevant factor in the proportionality analysis, a longlasting situation of de facto toleration, caused by inaction on the side of the authorities, has been indicated as highly pertinent by the Court. This has, so far, not been reflected in the domestic case law. Particularly relevant here is the French case which explicitly dismissed the presence of migrants on the site for an extended period of time as a relevant consideration. ${ }^{152}$ In addition, it could be argued that the protection for migrants should increase if they live in places designated by state authorities, since in such cases, the establishment of their homes cannot be classified as (entirely) unlawful. In Calais, for instance, the settlement from 2015-2016 combined a state-led site and makeshift camp, the former the result of 'persuasive measures' to go live in the field adjacent to the centre to receive the benefits provided by the latter. ${ }^{153}$ Thus rather than a tolerated stay, the state was complicit in the development of the camp as a whole. In Amsterdam, the occupation of the former prison (Vluchthaven) was lawful during the first six months, and only became unlawful after this period. As the ECtHR has held in Ivanova and Cherkezov, the nature and degree of the illegality at issue should be taken into account. This factor, however, did not play a role in the case about the eviction from the Vluchthaven in Amsterdam ${ }^{154}$ and in the cases about the more recent dismantlements in Calais. ${ }^{155}$

Thirdly, more and proper attention should be paid to the potentially vulnerable and underprivileged status of the migrants. It is important for domestic

\footnotetext{
$15^{2}$ Tribunal Administratif de Lille, 25 Février 2016, req. no. 1601386 (Sharifi \& autres), para 10.

153 Ibid.

154 District Court Amsterdam, 20 June 2014, ECLI:NL:RBAMS:2014:3532 and District Court Amsterdam, 4July 2014, ECLI:NL:RBAMS:2014:3952.

155 Tribunal Administratif de Lille, 25 Février 2016, req. no. 1601386 (Sharifi \& autres); Tribunal Administratif de Lille, 18 October 2016, req. no. 1607719 (M. Loay M. et autres).
} 
courts to differentiate between, on the one hand, the different individual circumstances of migrants and, one the other, the different categories of migrants such as (potential) asylum seekers, ${ }^{156}$ rejected asylum seekers, (unaccompanied) minors ${ }^{157}$ and adults etc. In the domestic case law discussed in section 3 , the vulnerability of migrants caused by their individual circumstances and specific group characteristics hardly played any role in the balancing exercise.

Fourthly, even if an eviction is considered to be necessary, factors such as a long period of de facto toleration and vulnerability of the persons concerned should be a factor of weight in deciding on the timing and modalities of the eviction. In one of the French cases, the migrants had argued that a one-week time-limit left to them before the implementation of the expulsion was held insufficient, ${ }^{158}$ a point which the Lille Administrative Tribunal did not reflect upon in its judgement, thereby actually ignoring this procedural safeguard.

Finally, the availability of alternative housing is an important factor. The ECtHR requires that the state should explicitly consider the possibilities for alternative accommodation, or the risk of becoming homeless, when taking a decision to evict. Contrary to the factors discussed above, this factor actually played an important role in the domestic case law. Indeed, the issue of availability of or entitlement to (alternative) housing seems to be the main decisive factor in cases about eviction from migrants' informal settlements in the domestic cases discussed in section 3. Article 8 ECHR case law, however, shows that other factors - such as a clear legal basis for the eviction; a proportionality analysis based on individual circumstances in every case; relevant circumstances being de facto toleration or even designation of living places by state authorities; and (group-based and individual) vulnerability — are just as important and merit the same level of attention by domestic courts.

In sum, we argue that migrants' informal settlements, as discussed in this article, qualify as 'home' within the meaning of Article 8 ECHR. In assessing evictions from or demolition of these settlements, the proper legal framework should be applied: namely, the state's negative obligations under Article 8

${ }_{15} 6$ As the ECtHR noted in MSS $v$ Belgium and Greece potential asylum seekers fall within the category of particularly vulnerable (M.S.S. $v$ Belgium and Greece Application No 30696/og, Merits, 21 January 2011, para 225).

157 According to the Court, whereas all asylum seekers are vulnerable, minor asylum seekers are 'extremely' vulnerable, even if they are accompanied by their parents (Tarakhel $v$ Switzerland Application No 29217/12, Merits, 4 November 2014) and children's vulnerability as a minor should take precedence over their irregular status (Mubilanzila Mayeka and Kaniki Mitunga v Belgium Application No 13178/03, Merits, 12 October 2006).

158 Tribunal Administratif de Lille, 25 Février 2016, req. no. 1601386 (Sharifi and others). 
ECHR, entailing the question whether the interference is justified. After analysing the published domestic case law on migrants' evictions in Amsterdam and Calais, we can conclude that this framework is either not invoked and/or applied at all, or the relevant factors stemming from ECtHR case law have not been raised and/or discussed in enough detail.

Even though the correct application of this framework would not result in a complete ban on evictions or dismantlements, we do believe that recognition of irregular migrants' right to respect for their home provides important protection. First of all, the recognition of procedural safeguards and attention for procedural quality has certain advantages for the individual, such as an increase in process efficacy ('good process for good outcomes'). ${ }^{159}$ Secondly, the case law of the ECtHR also offers more substantive protection. The ECtHR has shown how domestic courts should assess the proportionality and which factors should weigh heavily in this assessment. The analysis and examples above show that these factors have so far not played any serious role in the domestic case law. Correct application of the framework would, therefore, mean that it is harder for state authorities to justify an eviction, which increases the level of protection of migrant's right to respect for their home. Finally, the ECtHR case law does not only offer (procedural and substantive) protection against the actual eviction, but also with regard to the timing and modalities of the eviction. So far, this has hardly played a role in domestic case law. Explicit attention to the modalities and timing of evictions in domestic procedures could, however, help to safeguard adequate and timely information, and provide migrants sufficient time to prepare, collect their belongings and look for alternative shelter.

\section{$6 \quad$ Concluding Remarks}

Informal migrant settlements, such as makeshift camps or squats, even if they are sometimes very precarious, are migrants' 'homes' worthy of protection. Since these settlements have proliferated across the European Union, it has become even more important to treat the question of eviction and demolition

159 E. Brems, 'The 'Logics' of Procedural-Type Review by the European Court of Human Rights', in: J. Gerards \& E. Brems (eds.), Procedural Review in European Fundamental Rights Cases (Cambridge: Cambridge University Press, 2017), p. 17-39. Brems identified three other rationales for the procedural protection offered by the ECtHR: an increase in the perception of procedural justice, which, in social psychology, is held to be more significant than the perception of distributive justice; the subsidiary role of the ECtHR; and autonomous reasons of 'process value'. 
adequately. Drawing upon the cases of Calais and Amsterdam, this article has sought the added value of using the framework of review for states' negative obligations under the right to respect for a home of Article 8 ECHR. We argue that indeed, the Article 8 ECHR case law on the right to respect for a home provides a relevant and useful framework that should be used to evaluate the legitimacy of evictions and destructions of informal migrants' settlements. Despite the fact that applying this framework of review would not entail a complete ban on evictions and destructions, it provides necessary protection to migrants. This protection is of a procedural and substantive nature: the proportionality of the eviction or destruction should be assessed by a judge in every case, taking into account, and putting enough weight to, the relevant factors established in the ECtHR case law, and explicitly paying attention to the timing and modalities of the evictions and destructions. This article has shown that, at least for the migrants in Amsterdam and Calais, this protection has not been provided by domestic courts.

We have not dealt with the question if and to what extent states are under an obligation to provide some kind of shelter to (vulnerable) irregular migrants or to improve the often very poor living conditions in the makeshift camps and squats. While this is an important question from a legal and moral perspective, and can in real life not be ignored in discussing evictions and dismantlements, we have tried to add a new element to the discussion of irregular migrants' social rights. We believe that it is necessary to (also) think about irregular migrants' rights in terms of negative obligations of the state and to further examine the legal and practical consequences that this would entail. 